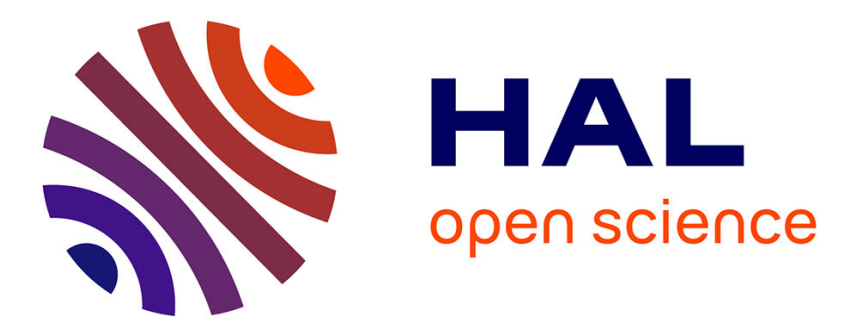

\title{
The effect of garnet and muscovite on the recrystallized grain size of quartz from general shear experiments
}

\author{
Leif Tokle, Greg Hirth, Luiz Morales, Holger Stunitz
}

\section{To cite this version:}

Leif Tokle, Greg Hirth, Luiz Morales, Holger Stunitz. The effect of garnet and muscovite on the recrystallized grain size of quartz from general shear experiments. EGU General Assembly 2020, May 2020, Online, France. 10.5194/egusphere-egu2020-8179 . hal-03554430

\author{
HAL Id: hal-03554430 \\ https://hal.science/hal-03554430
}

Submitted on 4 Feb 2022

HAL is a multi-disciplinary open access archive for the deposit and dissemination of scientific research documents, whether they are published or not. The documents may come from teaching and research institutions in France or abroad, or from public or private research centers.
L'archive ouverte pluridisciplinaire HAL, est destinée au dépôt et à la diffusion de documents scientifiques de niveau recherche, publiés ou non, émanant des établissements d'enseignement et de recherche français ou étrangers, des laboratoires publics ou privés.

\section{(c)(1)}

Distributed under a Creative Commons Attribution| 4.0 International License 
EGU2020-8179

https://doi.org/10.5194/egusphere-egu2020-8179

EGU General Assembly 2020

(c) Author(s) 2022. This work is distributed under

the Creative Commons Attribution 4.0 License.

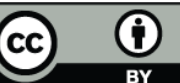

\title{
The effect of garnet and muscovite on the recrystallized grain size of quartz from general shear experiments
}

\author{
Leif Tokle ${ }^{1,2}$, Greg Hirth ${ }^{2}$, Luiz Morales ${ }^{1}$, and Holger Stunitz ${ }^{3,4}$ \\ ${ }^{1}$ Geological Institute, ETH, Zurich, Switzerland \\ ${ }^{2}$ Department of Earth Environmental, and Planetary Sciences, Brown University, Providence, USA \\ ${ }^{3}$ Institut des Sciences de la Terre d'Orléans, Université d'Orléans, Orléans, France \\ ${ }^{4}$ Department of Geology, University of Tromsø, Tromsø, Norway
}

To investigate the role of strong and weak secondary phases on the recrystallized grain size of quartz, we performed grain size analyses on quenched samples from general shear experiments on quartz-garnet and quartz-muscovite mixtures. Six general shear experiments were conducted in the Griggs apparatus; three with mixtures of quartz-garnet (vol.\% garnet 5, 15, 30) and three with mixtures of quartz-muscovite (vol.\% muscovite $5,10,25)$. The starting powders for both set of experiments were synthetic mixtures of quartz-muscovite or quartz-garnet with $0.1 \mathrm{wt} . \%$ water added. The quartz-garnet experiments were conducted at $900^{\circ} \mathrm{C}$, a pressure of $1.2 \mathrm{GPa}$, and a shear strain rate of $\sim 10^{-5} \mathrm{~s}^{-1}$, while the quartz-muscovite experiments were conducted at $800^{\circ} \mathrm{C}$, a pressure of $1.5 \mathrm{GPa}$, and a shear strain rate of $\sim 10^{-5} \mathrm{~s}^{-1}$. At these deformation conditions quartz is stronger than muscovite and weaker than garnet. We observed that the bulk strength of the aggregate decreases with a greater volume percent of muscovite and increases with a greater volume percent of garnet. Garnet at these conditions does not deform plastically. The presence of secondary phases within the deforming aggregate causes stress concentrations and partitioning of strain rate between the different phases relative to the measured bulk stress and strain rate. The degree of partitioning is primarily related to the rheology and volume percent of the phases. Due to the piezometric relationship between recrystallized grain size and stress, we can use the quartz recrystallized grain size to determine the local stress of quartz in the experiments and compare it to the measured bulk stress. The results from these analyses will provide new insight into the effect of strain partitioning in general and of strong and weak secondary phases on quartz rheology. 